\title{
Isotope baseline shifts in pelagic food webs of the Gulf of Mexico
}

\author{
Samuel Dorado ${ }^{1}$, Jay R. Rooker ${ }^{1}$, Björn Wissel ${ }^{2}$, Antonietta Quigg ${ }^{1,3, *}$ \\ ${ }^{1}$ Department of Marine Biology, Texas A\&M University at Galveston, 200 Seawolf Parkway, Galveston, Texas 77553, USA \\ ${ }^{2}$ Department of Biology, University of Regina, 265.2 Laboratory Building, Regina, Saskatchewan S4S 0A2, Canada \\ ${ }^{3}$ Department of Oceanography, Texas A\&M University, 3146 TAMU, College Station, Texas 77843, USA
}

\begin{abstract}
Diazotrophic inputs by Trichodesmium have been shown to support production in tropical and subtropical marine environments, but the importance of Trichodesmium in the Gulf of Mexico has not been widely investigated. Here, we use stable carbon $\left(\delta^{13} C\right)$ and nitrogen $\left(\delta^{15} N\right)$ isotopes to determine whether diazotrophy impacts the isotope baselines of pelagic food webs in the northern Gulf of Mexico. Phytoplankton (measured as particulate organic matter), Trichodesmium, and zooplankton were collected from neritic and oceanic environments (salinity $<32$ and $\geq 32$, respectively). Our results show that zooplankton in both regions exhibited $\delta^{13} \mathrm{C}$ values that were constrained between -20 and $-18 \%$, which reflects the use of carbon from both Trichodesmium and other phytoplankton. Despite the utilization of similar carbon sources, zooplankton $\delta^{15} \mathrm{~N}$ values were significantly higher in neritic (mean $\pm \mathrm{SD}=5.4 \pm 1.1 \%$ ) compared to oceanic samples $(2.8 \pm 1.4 \%)$. We attribute the difference in nitrogen isotope values to the use of isotopically light nitrogen derived from diazotrophy in oceanic environments compared to enriched nitrogen from terrestrial sources transported by rivers in neritic areas. A comparison with published food web data from the Gulf of Mexico shows that disparate $\delta^{15} \mathrm{~N}$ values which parallel our data suggest differential nitrogen cycling throughout the basin. The results of the present study indicate that diazotrophy impacts the estimation of consumer trophic positions by altering the $\delta^{15} \mathrm{~N}$ values of organisms at the base of the food web. $\mathrm{N}_{2}$ fixation and freshwater inputs should be considered in future efforts to describe pelagic food webs in the Gulf of Mexico.
\end{abstract}

KEY WORDS: Stable isotopes $\cdot \delta^{13} \mathrm{C} \cdot \delta^{15} \mathrm{~N} \cdot$ Trichodesmium $\cdot$ Particulate organic matter $\cdot \mathrm{POM} \cdot$ Nitrogen fixation $\cdot$ Food web $\cdot$ Gulf of Mexico $\cdot$ Zooplankton

\section{INTRODUCTION}

It is important to identify the biological and physical processes that introduce new combined nitrogen $(\mathrm{N})$, as such $\mathrm{N}$ stimulates primary producers (phytoplankton) that support higher trophic levels: zooplankton and larval fishes (Dugdale \& Goering 1967, Eppley \& Peterson 1979). Upwelling of nitrate $\left(\mathrm{NO}_{3}{ }^{-}\right)$ from the euphotic zone was thought to be the primary source of $\mathrm{N}$ supporting production in open ocean systems, while the biological fixation of atmospheric nitrogen $\left(\mathrm{N}_{2}\right)$, riverine sources, and atmospheric deposition of $\mathrm{N}$ were considered ancillary
(Eppley \& Peterson 1979). Using molecular techniques and isotopes as tracers, this classic view was challenged. We now know that cyanobacteria in the open ocean can fix $\mathrm{N}_{2}$ (Zehr et al. 1998) and can drive production by supplying significant amounts of fixed $\mathrm{N}$ to the photic zone (Capone et al. 2005). Freshwater inputs have also been shown to impact phytoplankton community composition and primary production (Howarth \& Marino 2006, Quigg et al. 2011). In addition, circulation patterns have been shown to entrain freshwater masses and carry them into the offshore marine environment (Biggs \& Ressler 2001, Biggs et al. 2008). Assessing the importance of non-traditional 
processes, such as $\mathrm{N}_{2}$ fixation and riverine inputs, using stable isotope techniques may help to explain the success of higher trophic levels in open ocean environments.

Calculating the natural abundance of nitrogen stable isotopes $\left(\delta^{15} \mathrm{~N}\right)$ involves comparing the nitrogen isotope ratios $\left({ }^{15} \mathrm{~N}:{ }^{14} \mathrm{~N}\right)$ of a sample to an atmospheric $\mathrm{N}_{2}$ standard. Shifts in isotope abundance result from fractionation that occurs during chemical reactions that transform $\mathrm{N}$, such as $\mathrm{N}_{2}$ fixation and denitrification (Peterson \& Fry 1987, Montoya 2008). There are many studies which show that fractionation is significant during inorganic $\mathrm{N}$ uptake and assimilation by phytoplankton based on species, cell size, growth rates, light, and nutrient concentrations (York et al. 2007). However, phytoplankton biomass $\delta^{15} \mathrm{~N}$ values become similar to their inorganic source $\delta^{15} \mathrm{~N}$ values when $\mathrm{N}$ becomes limiting in aquatic systems (Altabet et al. 1986, York et al. 2007, Montoya 2008). Measuring $\delta^{15} \mathrm{~N}$ of particulates in the marine environment can therefore be useful in estimating the relative importance of isotopically distinct nitrogen sources, such as deepwater $\mathrm{NO}_{3}{ }^{-}$or $\mathrm{N}_{2}$, supporting phytoplankton growth. In addition, $\delta^{15} \mathrm{~N}$ values of consumers are typically enriched by 3 to $4 \%$ compared to their prey, a difference which has permitted the use of $\delta^{15} \mathrm{~N}$ values to calculate trophic position (Post 2002). When carbon stable isotope $\left(\delta^{13} \mathrm{C}\right)$ measurements are also taken into consideration, information on the source of organic carbon, hence food web structure, is gained (Peterson \& Fry 1987, Fry 2008). To apply these methods, an accurate estimation of an isotopic baseline must be calculated using the $\delta^{15} \mathrm{~N}$ values of all potential producers forming the base of the food web (Post 2002). Differential N sources therefore impact the $\delta^{15} \mathrm{~N}$ values and trophic position of consumers by altering the $\delta^{15} \mathrm{~N}$ values of organisms supporting them. Documenting these shifts in the pelagic realm will ultimately help answer questions concerning production in oligotrophic environments resulting from the use of different $\mathrm{N}$ sources.

Previous studies in the Gulf of Mexico (GOM) have used $\delta^{13} \mathrm{C}$ and $\delta^{15} \mathrm{~N}$ values of producers and consumers to characterize trophic relationships of fishes in pelagic environments (Table 1). In these studies, phytoplankton (measured as particulate organic matter, POM) and Sargassum spp. (hereafter Sargassum) were identified as important producers that supply organic matter to higher trophic levels (Rooker et al. 2006, Wells \& Rooker 2009). Similar methods have been applied to show that $\mathrm{N}_{2}$ fixation (diazotrophy) by Trichodesmium spp. (hereafter Trichodesmium) supports large zooplankton assemblages in offshore regions of the western GOM (Holl et al. 2007). Depleted $\delta^{15} \mathrm{~N}$ signatures in consumer tissues have been documented to occur in areas where $\mathrm{N}_{2}$ fixation is thought to contribute significantly to new production in the East China, Sargasso, and Mediterranean seas and the western Atlantic Ocean (Minagawa \& Wada 1986, Gruber \& Sarmiento 1997, Montoya et al. 2002, Capone et al. 2005). Depleted $\delta^{15} \mathrm{~N}$ values measured in consumers by Wells \& Rooker (2009) suggest $\mathrm{N}_{2}$ fixation plays a role, but this process has not been documented in the northern GOM.

In the present study, $\delta^{13} \mathrm{C}$ and $\delta^{15} \mathrm{~N}$ values of POM, Trichodesmium, and zooplankton were measured in areas of the northern GOM to evaluate whether diazotrophy impacts the isotopic baseline of food webs where important larval and juvenile fishes are known to occur. The isotope data were then compared to salinity, phytoplankton pigment, and nutrient concentrations to attribute differences to freshwater influence. We hypothesize that organisms collected from areas where Trichodesmium is abundant will retain significantly depleted $\delta^{15} \mathrm{~N}$ values compared to those in areas where concentrations of this cyanobacterium are low. To assess the mechanisms responsible for differences observed in our consumer isotope values, published food web data from the GOM were compared to isotope differences reported by Pajuelo et al. (2010), who attribute isotopic baseline shifts in the Atlantic and Pacific oceans to differences in basin-scale $\mathrm{N}_{2}$ fixation and denitrification. The present study aims to show that ecosystem function within the GOM can be attributed to the utilization of different $\mathrm{N}$ sources by the planktonic community. Specifically, we provide examples of how the products of diazotrophy and terrestrially derived $\mathrm{N}$ impact isotopic baselines within the GOM, which confound the interpretation of consumer trophic positions. The results provide further insight into the early life ecology of pelagic fishes in oligotrophic environments and will help direct future research to identify differential resource acquisition in aquatic ecosystems.

\section{MATERIALS AND METHODS}

\section{Study area}

Samples were collected from 36 stations aboard the RV 'Ladybride' during ichthyoplankton surveys conducted in the northern GOM in surface waters off Texas, Louisiana, and Mississippi, USA, $\left(26\right.$ to $28^{\circ} \mathrm{N}$ and 86 to $94^{\circ} \mathrm{W}$ ) during June and July 2009 (Fig. 1, Fig. S1 in the supplement at www.int-res.com/articles/ 
Table 1. Published stable isotope values for producers and consumers in the Gulf of Mexico. The selection of data included herein is explained in detail in 'Materials and methods: Data analysis'. na: data not available

\begin{tabular}{|c|c|c|c|c|}
\hline Species & $\mathrm{n}$ & $\delta^{13} \mathrm{C}(\%)$ & $\delta^{15} \mathrm{~N}(\%)$ & Source \\
\hline \multicolumn{5}{|l|}{ Neritic } \\
\hline \multicolumn{5}{|l|}{ Primary producers } \\
\hline \multirow[t]{3}{*}{ POM } & 22 & $-20.0 \pm 1.4$ & $7.5 \pm 0.8$ & Macko et al. (1984) \\
\hline & 14 & $-20.1 \pm 1.8$ & $8.0 \pm 3.0$ & Rooker et al. (2006) \\
\hline & 67 & $-24.9 \pm 1.2$ & $9.3 \pm 1.4$ & Wissel et al. (2005) \\
\hline Sargassum spp. & 29 & $-16.9 \pm 0.9$ & $2.6 \pm 1.6$ & Rooker et al. (2006) \\
\hline \multicolumn{5}{|l|}{ Secondary consumers } \\
\hline Zooplankton & 22 & $-19.2 \pm 0.7$ & $8.9 \pm 0.9$ & Macko et al. (1984) \\
\hline Shrimp Panaeus sp. & 22 & $-15.6 \pm 1.1$ & $12.9 \pm 1.1$ & Macko et al. (1984) \\
\hline \multicolumn{4}{|l|}{ Juvenile fishes } & Rooker et al. (2006) \\
\hline Sargeant major Abudefduf saxatilis & 5 & $-18.0 \pm 0.3$ & $10.7 \pm 0.4$ & \\
\hline Dotterel filefish Aluterus heudeloti & 3 & $-18.6 \pm 1.5$ & $12.9 \pm 0.7$ & \\
\hline Scrawled filefish Aluterus scriptus & 4 & $-17.9 \pm 0.4$ & $13.0 \pm 0.5$ & \\
\hline Yellow jack Caranx bartholomaei & 4 & $-16.5 \pm 0.3$ & $13.5 \pm 0.3$ & \\
\hline Blue runner Caranx crysos & 23 & $-17.3 \pm 0.3$ & $9.5 \pm 0.9$ & \\
\hline Sargassum fish Histrio histrio & 11 & $-18.0 \pm 0.8$ & $10.1 \pm 2.0$ & \\
\hline Planehead filefish Monocanthus hispidus & 11 & $-18.4 \pm 0.7$ & $10.1 \pm 1.2$ & \\
\hline Freckled driftfish Psenes cyanophrys & 5 & $-17.6 \pm 0.4$ & $13.8 \pm 0.9$ & \\
\hline Greater amberjack Seriola dumerili & 12 & $-18.3 \pm 0.4$ & $10.2 \pm 1.3$ & \\
\hline Almano jack Seriola rivoliana & 4 & $-17.0 \pm 0.6$ & $13.6 \pm 0.5$ & \\
\hline Chain pipefish Syngnathus louisianae & 5 & $-17.8 \pm 0.4$ & $11.1 \pm 0.9$ & \\
\hline Sargassum pipefish Syngnathus pelagicus & 5 & $-16.9 \pm 0.8$ & $11.3 \pm 0.6$ & \\
\hline Yellowfin tuna Thunnus albacares & 2 & $-16.6 \pm 0.5$ & $7.8 \pm 1.7$ & \\
\hline \multicolumn{5}{|l|}{ Oceanic } \\
\hline \multicolumn{5}{|l|}{ Primary producers } \\
\hline Trichodesmium spp. & na & -15 to -13 & -2 to -1 & Holl et al. (2007) \\
\hline \multirow[t]{2}{*}{ POM } & 19 & $-22.2 \pm 1.4$ & $2.7 \pm 1.9$ & Wells \& Rooker (2009) \\
\hline & na & -23 to -27 & 1 to 3.2 & Holl et al. (2007) \\
\hline Sargassum spp. & 16 & $-17.3 \pm 1.4$ & $0.8 \pm 1.5$ & Wells \& Rooker (2009) \\
\hline \multicolumn{5}{|l|}{ Secondary consumers } \\
\hline \multirow[t]{2}{*}{ Zooplankton } & na & -17.5 to -19.5 & 1 to 3 & Holl et al. (2007) \\
\hline & 30 & $-18.4 \pm 1.1$ & $5.9 \pm 0.7$ & Macko et al. (1984) \\
\hline Shrimp Panaeus sp. & 30 & $-14.8 \pm 0.5$ & $8.4 \pm 0.9$ & Macko et al. (1984) \\
\hline Larval fishes & & & & Wells \& Rooker (2009) \\
\hline Blue marlin Makaira nigricans & 46 & $-19.0 \pm 1.0$ & $2.2 \pm 0.7$ & \\
\hline Dolphinfish Coryphaena hippurus & 10 & $-18.2 \pm 0.9$ & $4.9 \pm 1.5$ & \\
\hline Pompano dolpinfish Coryphaena equiselis & 8 & $-19.3 \pm 1.2$ & $5.5 \pm 1.0$ & \\
\hline Sailfish Istiophorus platypterus & 40 & $-20.1 \pm 0.6$ & $4.3 \pm 1.2$ & \\
\hline Swordfish Xiphias gladius & 31 & $-18.5 \pm 1.1$ & $4.4 \pm 0.8$ & \\
\hline Juvenile fishes & & & & Wells \& Rooker (2009) \\
\hline Dolphinfish Coryphaena hippurus & 15 & $-17.7 \pm 0.5$ & $6.7 \pm 1.7$ & \\
\hline Pompano dolphinfish Coryphaena equiselis & 16 & $-18.6 \pm 1.2$ & $8.1 \pm 1.7$ & \\
\hline Sailfish Istiophorus platypterus & 10 & $-18.2 \pm 0.2$ & $6.4 \pm 1.1$ & \\
\hline Swordfish Xiphias gladius & 10 & $-18.2 \pm 0.7$ & $4.1 \pm 1.3$ & \\
\hline
\end{tabular}

suppl/m464p037_supp.pdf). This region of the GOM functions as a natural experimental system to assess the utilization of differential $\mathrm{N}$ sources because $\mathrm{N}_{2}$ fixation and freshwater inputs of $\mathrm{N}$ have been shown to enhance primary and secondary production by alleviating N limitation (Walsh et al. 1989, Biggs \& Ressler 2001, Dagg \& Breed 2003, Holl et al. 2007, Quigg et al. 2011). During summer months, the northern GOM is influenced by inshore (hereafter, neritic) waters from the Mississippi and Atchafalaya rivers (Walker et al. 2005, Biggs et al. 2008) in addition to the shedding of warm-core eddies by the Loop Current (LC) in offshore (hereafter, oceanic) regions (Biggs \& Ressler 2001). During the course of our study, the eastern sections of our sampling transects were dominated by the western edge of the LC, while the western sections transected a warm-core eddy (see Fig. S1 in the supplement). During July, we also transected water masses that exhibited decreased salinities and increased turbidity, which we 


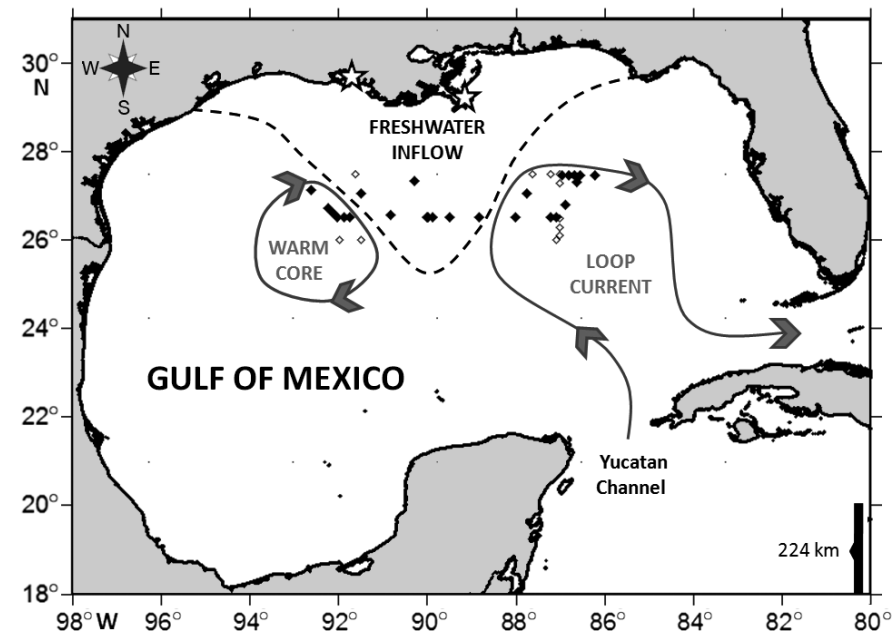

Fig. 1. Map of study area in the Gulf of Mexico (GOM) showing sampling points and encountered water masses. During cruises in $(\diamond)$ June and $(\diamond)$ July 2009, 36 stations were sampled. The Mississippi River and Atchafalaya River (t) are important sources of freshwater in the northern GOM during the spring/summer, and the relative area of the plume encountered in July is outlined by the black dashed line. The Loop Current was also sampled during our study period and is the source of oceanic water masses (grey solid lines) in the Gulf. The Loop Current enters through the Yucatan Channel, and as it circulates clockwise through the Gulf, it typically sheds warm core eddies, one of which was also sampled during June and July

considered entrainments of freshwater from the Mississippi River. Prior to sampling, the LC, associated eddies, and the Mississippi River plume were identified using sea surface height (SSH) and sea surface chlorophyll (SSC) maps (Colorado Center for Astrodynamics Research; http://argo.colorado.edu/ realtime/) (see Fig. S1 in the supplement).

\section{Sample collection}

POM, Trichodesmium, and zooplankton were collected from surface waters $(<1 \mathrm{~m})$ by towing plankton nets (mesh size: $20 \mu \mathrm{m}$ for POM, and $333 \mu \mathrm{m}$ for zooplankton and Trichodesmium, respectively) for a maximum of $10 \mathrm{~min}$. POM collections targeted net or micro-phytoplankton (20 to $200 \mu \mathrm{m})$ that are likely the food source of the meso-zooplankton (0.2 to $2 \mathrm{~mm}$ ) assessed in the present study (Sieburth et al. 1978). Large colonies of Trichodesmium were isolated using sterile metal inoculating loops and transferred to a Nitex sieve (20 $\mu \mathrm{m}$ mesh). Zooplankton assemblages were isolated using sterilized forceps, and large zooplankton (chaetognaths, gelatinous masses, copepods, and other crustaceans) were transferred to a Nitex sieve $(120 \mu \mathrm{m}$ mesh). After collection, each sample was rinsed 3 times with filtered seawater $(0.2 \mu \mathrm{m})$ and then filtered onto a pre-combusted $\left(400^{\circ} \mathrm{C}\right.$ for $5 \mathrm{~h}$ ) Whatman GF/F (nominal pore size of $0.7 \mu \mathrm{m}$ ), which was subsequently folded and immediately frozen $\left(-20^{\circ} \mathrm{C}\right)$.

Salinity (herein reported using the unit-less practical salinity scale) measurements were taken at all stations using a calibrated Hydrolab, while samples for pigment and nutrient analysis were taken at $\sim 45 \%$ of the stations. Phytoplankton pigment samples were collected after manually concentrating $40 \mathrm{l}$ of seawater using a plankton net (mesh size: $20 \mu \mathrm{m}$ ). The concentrate was filtered onto a Whatman GF/F and immediately frozen until later analysis at the University of South Carolina HPLC facility (J. Pinckney). Nutrient samples were analyzed for nitrate $\left(\mathrm{NO}_{3}{ }^{-}\right)$, nitrite $\left(\mathrm{NO}_{2}{ }^{-}\right)$, ammonium $\left(\mathrm{NH}_{4}{ }^{+}\right)$, phosphate $\left(\mathrm{HPO}_{4}{ }^{-}\right)$, silicate $\left(\mathrm{SiO}_{2}\right)$, and urea concentrations by collecting surface water in $50 \mathrm{ml}$ centrifuge tubes that were acid-washed $(1 \mathrm{~N} \mathrm{HCl})$ prior to use. Samples were immediately frozen after collection and sent to the Geochemical and Environmental Research Group at Texas A\&M University for analysis. Dissolved inorganic nitrogen (DIN) was calculated by adding the concentrations of $\mathrm{NO}_{3}{ }^{-}, \mathrm{NO}_{2}{ }^{-}$, and $\mathrm{NH}_{4}{ }^{+}$ and was used to calculate the DIN:P ratio.

\section{Stable isotope analysis}

Filters were dried at $60^{\circ} \mathrm{C}$ until a stable dry weight was reached. For POM analysis, 6 hole punches were taken from individual filters and packed into tin cups. For Trichodesmium and zooplankton samples, 0.5 to $1.0 \mathrm{mg}$ of dry material was scraped off the filters and packed into tin cups. Isotope ratios were determined using a Thermo Finnigan Deltaplus isotope ratio mass spectrometer that was coupled to a Costech elemental analyzer according to Wissel et al. (2005) and Wissel \& Fry (2005a). Stable carbon and nitrogen abundance were calculated according to Eq. (1) by comparing the ratios of the heavy to light isotopes of the sample to those of a known standard and are reported as $\delta^{15} \mathrm{~N}$ or $\delta^{13} \mathrm{C}$ :

$\delta^{13} \mathrm{C}$ or $\delta^{15} \mathrm{~N}(\%)=\left[\left(\mathrm{R}_{\text {sample }} / \mathrm{R}_{\text {standard }}\right)-1\right] \cdot 1000$

where $\mathrm{R}$ is ${ }^{13} \mathrm{C}:{ }^{12} \mathrm{C}$ or ${ }^{15} \mathrm{~N}:{ }^{14} \mathrm{~N}$. Values are relative to international standards of Vienna Pee Dee Belemnite and atmospheric nitrogen for carbon and nitrogen, respectively. The accuracy of the measurements was $0.2 \%$ for both $\delta^{15} \mathrm{~N}$ and $\delta^{13} \mathrm{C}$. 


\section{Data analysis}

The R computing environment (version 2.9.0, www. r-project.org/) and vegan library (version 1.15-3) were used to assess similarity in isotope values and characterize water masses according to salinity, pigment, and nutrient concentrations using cluster and non-metric multidimensional scaling (NMDS) analyses. Multivariate analysis of variance (MANOVA) and analysis of variance (ANOVA) tests were run using SPSS (version 17.0) to establish whether stable isotope values of the POM, Trichodesmium, and zooplankton were significantly different between groups identified using agglomerative clustering. ANOVA was then used to assess whether significant differences in isotope values were driven by changes in $\delta^{13} \mathrm{C}, \delta^{15} \mathrm{~N}$, or both. Non-transformed data were used for these analyses, and the normality and homogeneity of variance assumptions were tested using Kolmogorov-Smirnov and Levene's tests, respectively. The stable isotope data were not distributed normally; therefore, significance was established if p-values were less than or equal to an adjusted Pillai trace value of 0.025 or an adjusted Bonferroni alpha level of 0.025 (Pallant 2010) for MANOVA and ANOVA, respectively. Observed power $(1-\beta)$, where $\beta$ equals the probability of a Type II error, was also calculated for each statistical test to assess the chances for Type II errors. Means of isotope and environmental data are presented with standard deviations unless otherwise noted.

For cluster analyses, POM stable isotope data were $\log _{10}(|x|+1)$ transformed to remove negative values and scale data appropriately. Transformed isotope data were then categorized based on where the sample was taken and salinity measurements. Stations were categorized as originating from the LC, warm core eddy (WC), or freshwater entrainment (FW) prior to analysis, which allowed us to determine whether separation during cluster analysis could be attributed to freshwater influence. Stations were considered to be influenced by freshwater if measurements were below $32 \mathrm{psu}$; salinities of oceanic waters are typically higher. The transformed data were then used to calculate a triangular similarity matrix using the Bray-Curtis index, and a dendrogram was created using the agglomerative average linkage method, also known as the unweighted pair group method with arithmetic mean.

Environmental data from a subset of stations were then $\log _{10}(|X|+1)$ transformed, and the corresponding transformed POM data were subjected to NMDS using the metaMDS procedure in the vegan library. This allowed us to visualize the similarity among sta- tions in ordination space and perform an unconstrained ecological interpretation of the ordination using environmental vector fitting (Oksanen et al. 2009) similar to methods published by Olli et al. (2011). This approach allowed us to describe the water masses and attribute variation in the isotopic composition of POM to significant differences in salinity, nutrient concentrations, the relative abundance of accessory pigments, and molar C:N ratios. The correlation between these environmental parameters and ordination scores was assessed using a coefficient of determination $\left(\mathrm{R}^{2}\right)$, which is expressed as a vector on the NMDS plot. The significance of the environmental parameters ( $p$-values) was determined by running random permutations of the data using methods outlined by Olli et al. (2011). Eqs. (2) \& (3) were used to calculate the relative abundance of accessory pigments; pigment concentration data were divided by the respective chlorophyll a concentration (standardized to the maximum):

$$
\mathrm{xAP}_{1,2, \ldots \mathrm{n}} / \mathrm{xCHL}_{1,2, \ldots \mathrm{n}}=\mathrm{x}_{1,2, \ldots \mathrm{n}}^{\prime}
$$

and then divided by the sum of all of the accessory pigments (standardized to the total):

$$
\mathrm{x}^{\prime}{ }_{1,2, \ldots \mathrm{n}} / \mathrm{x}^{\prime}{ }_{1,2, \ldots \mathrm{n}}
$$

where $\mathrm{xAP}$ is the concentration of accessory pigment, and $\mathrm{xCHL}$ is the concentration of chlorophyll $a$. The result is equal to the fraction of each accessory pigment in relation to 1 chlorophyll a molecule and is equivalent to Wisconsin double standardization commonly used in ecological community analysis methods (Oksanen et al. 2009, Olli et al. 2011). This pigment matrix was used to determine the relative importance of algal groups using environmental vector fitting. Finally, the molar $\mathrm{C}: \mathrm{N}$ ratios of samples were compared to published molar $\mathrm{C}: \mathrm{N}$ ratios from the Mississippi River to further attribute the change in isotope values to terrestrial inputs.

To determine whether isotope shifts in our data were related to the use of different $\mathrm{N}$ sources, we compared published producer and consumer isotope data from the GOM to juvenile loggerhead sea turtle Caretta caretta isotope data from Pajuelo et al. (2010) using a cross-plot of $\delta^{13} \mathrm{C}$ and $\delta^{15} \mathrm{~N}$. Table 1 summarizes the stable isotope literature regarding producers and consumers of pelagic food webs from studies that collected isotope data in neritic and oceanic regions of the GOM. When data were not made available by authors, we only utilized studies that presented $\delta^{13} \mathrm{C}$ and $\delta^{15} \mathrm{~N}$ property plots as the data could be accurately extracted using Engauge Digitizer (4.1). We utilized 2 publications in which data were collected 


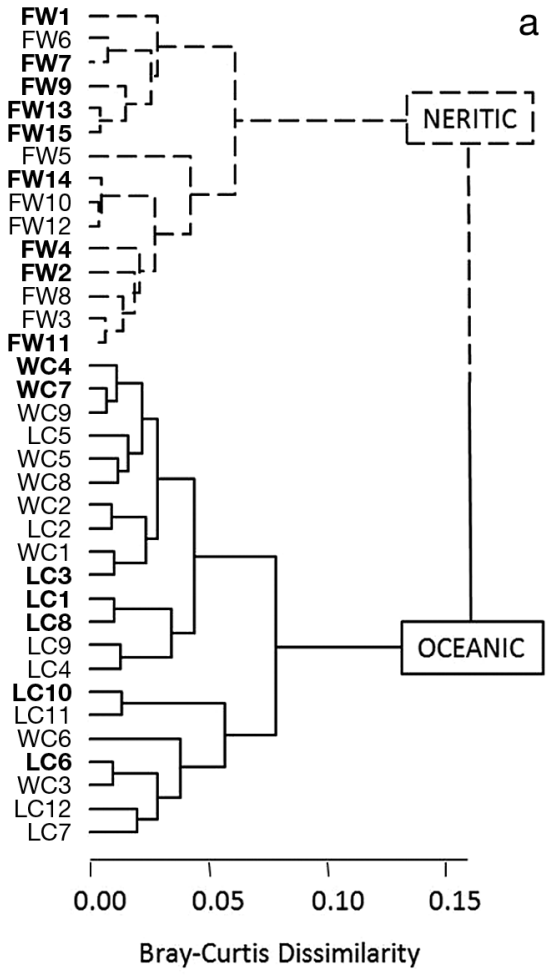

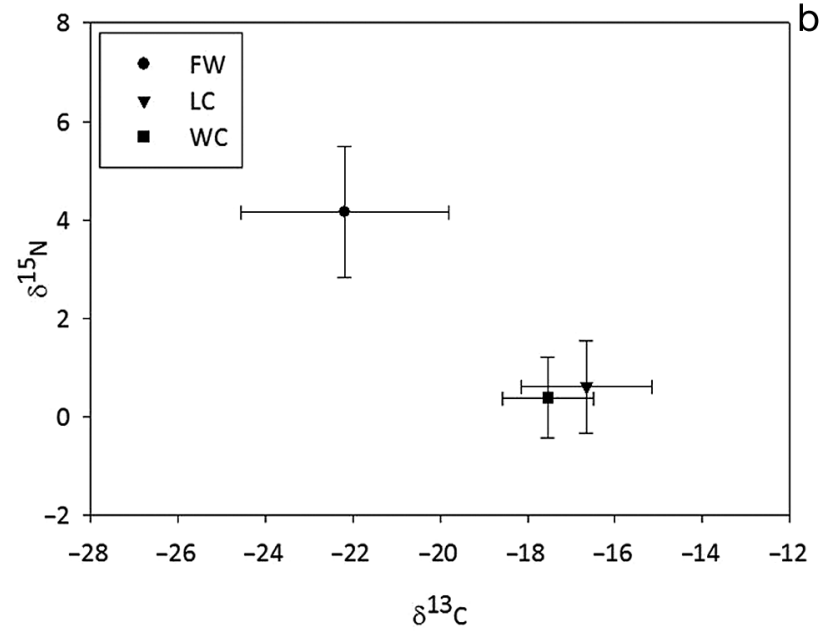

Fig. 2. Differences in particulate organic matter (POM) stable carbon $\left(\delta^{13} \mathrm{C}\right)$ and nitrogen $\left(\delta^{15} \mathrm{~N}\right)$ isotopes identified using (a) a dendrogram that shows the 2 major clusters identified using agglomerative clustering. Data were categorized as originating from the Loop Current (LC), warm core eddy (WC), or freshwater entrainment (FW) prior to analysis, and stations used for nMDS are in bold. (b) Average ( \pm 1 SD) isotope values of the categories ( $\mathrm{LC}, \mathrm{WC}$, and $\mathrm{FW}$ ) indicate that separation is based on differences in both carbon and nitrogen from neritic environments (Wissel \& Fry 2005b, Rooker et al. 2006) and 2 in which data were collected from oceanic areas (Holl et al. 2007, Wells \& Rooker 2009). In addition, we used data from Macko et al. (1984), who presented results from both neritic and oceanic areas of the GOM. Fry (1983), Senn et al. (2010), and Fry (2011) present significant data but were not included in our analyses due to the difficulty associated with accurately extracting the data.

\section{RESULTS}

\section{Stable isotope analysis}

Cluster analysis of POM carbon and nitrogen stable isotope data identified 2 major station assemblages (Fig. 2). Cluster 1 consists of 15 stations that were influenced by freshwater (salinity < 32) from July only, while Cluster 2 is composed of \pm 21 stations from both June (11) and July (10) that originated from the LC or WC feature (salinity > 32). Therefore, the assemblages coincided with similarity in salinity (hence, water mass). This indicates that spatial and temporal variability in stable isotope values is important and that differences in isotope values are attributed to the presence/absence of freshwater from the Mississippi and Atchafalaya River system.

Isotope values of POM and zooplankton were significantly different between neritic and oceanic water masses identified using cluster analysis (MANOVA, Pillai's trace $\leq 0.025$ ) (Table 2). ANOVA results indicated that $\delta^{13} \mathrm{C}$ values of POM were significantly depleted in neritic (mean $\pm \mathrm{SD}=-22.2 \pm 2.3 \%$ ) relative to oceanic $(-17.0 \pm 1.3 \%$ o $)$ water masses, while the trend was reversed for $\delta^{15} \mathrm{~N}$ (neritic: $4.2 \pm 1.3 \%$,

Table 2. Range and mean \pm SD stable isotope values of POM, Trichodesmium, and zooplankton for neritic and oceanic stations. ${ }^{*} \mathrm{p}<0.001$ between groups according to a Pillai trace value of $<0.025$. For insignificant results, observed power values are given in parentheses

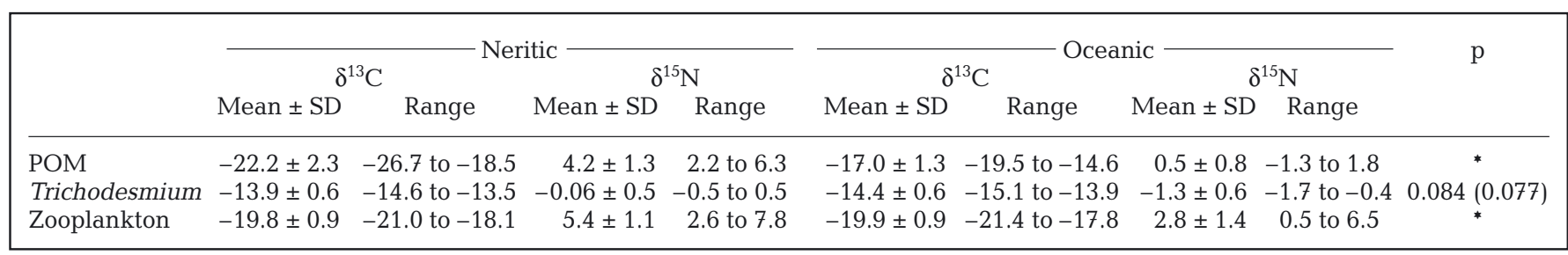




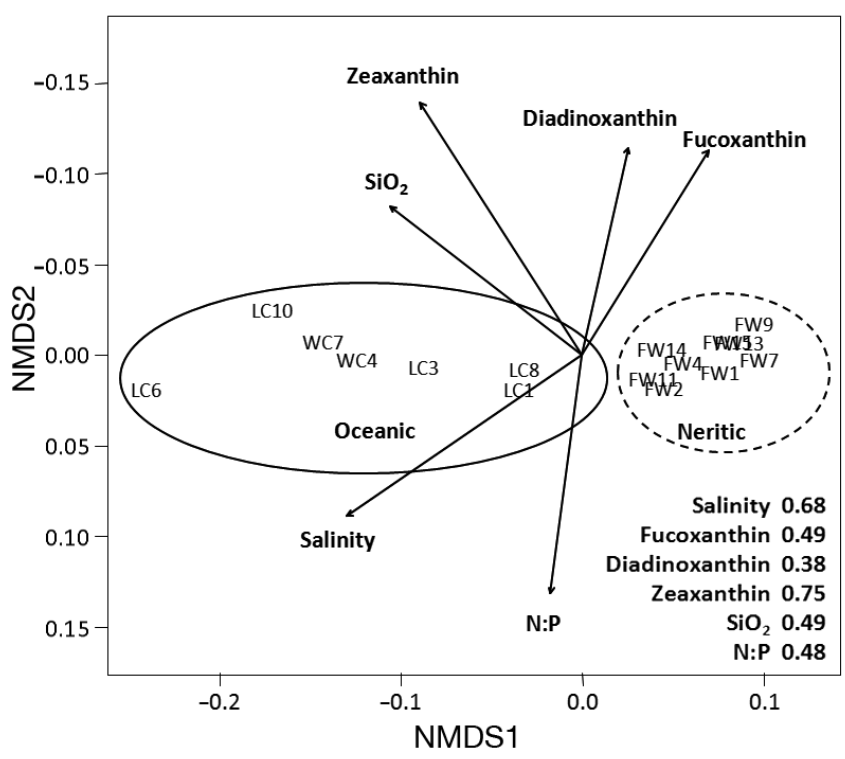

Fig. 3. Distribution of sites visualized in ordination space using NMDS coupled to environmental vector fitting, which depicts the strength of significant environmental variables that correlate to the NMDS axes. Neritic stations lie on the positive NMDS Axis 1, where diatom pigment concentrations (fucoxanthin and diadinoxanthin) are increased. Oceanic stations are distributed along the negative NMDS Axis 1, where salinity and concentrations of silicate and the pigment zeaxanthin are elevated. The numerical values on the lower left section of the ordination plot are equal to the correlation $\left(\mathrm{R}^{2}\right)$ between the environmental parameter and ordination scores

oceanic $0.5 \pm 0.8 \%$ o) $(\mathrm{p}=0.001)$. For zooplankton, ANOVA indicated that differences in $\delta^{15} \mathrm{~N}$ values between the neritic $(5.4 \pm 1.1 \%)$ and oceanic $(2.8 \pm 1.4 \%)$ water masses were significant $(p=0.001)$, but differences in $\delta^{13} \mathrm{C}$ values were not $(\mathrm{p}$ $=0.707)$. The similarity in zooplankton $\delta^{13} \mathrm{C}$ values (neritic: $-19.8 \pm 0.9 \%$, oceanic: $-19.9 \pm 0.9 \%$ ) suggests the use of a similar carbon source by zooplankton (oceanic phytoplankton and bacteria), while the wide range of $\delta^{15} \mathrm{~N}$ values is likely attributed to shifts in the isotopic baseline between neritic and oceanic environments.

\section{Freshwater influence}

nMDS coupled to environmental vector fitting showed that environmental conditions between neritic and oceanic stations were distinct (Fig. 3). Neritic stations occurred on the positive side of the NMDS
Axis 1, while oceanic stations lie on the negative side (Fig. 3). Environmental parameters that significantly (Pearson's correlation coefficient p-value $<0.05$ ) correlated to the 2-dimensional NMDS solution included salinity, silicate, DIN:P, and the accessory pigments zeaxanthin, fucoxanthin, and diadinoxanthin (Table 3). The strength and gradient of the accessory pigments fucoxanthin and diadinoxanthin indicated that these parameters were significantly greater at neritic stations where POM $\delta^{13} \mathrm{C}$ was depleted and POM $\delta^{15} \mathrm{~N}$ was enriched. In contrast, the gradient and strength of salinity, silicate, DIN:P, and zeaxanthin vectors indicated that values for these parameters were significantly greater at oceanic stations where POM $\delta^{13} \mathrm{C}$ was enriched and POM $\delta^{15} \mathrm{~N}$ was depleted.

Phytoplankton pigments have been used as chemical biomarkers to estimate phytoplankton biomass and identify dominant phytoplankton groups in the northern GOM (Lambert et al. 1999, Qian et al. 2003). Overall, zeaxanthin and chlorophyll $c 1 c 2$ were the most dominant accessory pigments (Table 3 ) but only the relative abundance of zeaxanthin significantly correlated with the nMDS solution. For oceanic stations, the accessory pigment contribution of zeaxanthin was greater than at neritic stations, indicating that cyanobacteria were dominant in these surface waters (Fig. 3, Table 3). At neritic stations, fucoxanthin and diadinoxanthin were dominant, indicating that diatoms and other eukaryotic phytoplankton were more prevalent in these surface waters (Fig. 3, Table 3).

Table 3. Environmental parameter cluster averages $\pm \mathrm{SD}$, correlation $\left(\mathrm{R}^{2}\right)$, and $\mathrm{p}$-values (significant parameters in bold) between environmental vectors and NMDS solution. DIN: dissolved inorganic nitrogen. ${ }^{*} \mathrm{p}<0.05,{ }^{* * *} \mathrm{p}<0.001$

\begin{tabular}{|c|c|c|c|}
\hline & $\begin{array}{c}\text { Neritic } \\
\text { Mean } \pm \text { SD }\end{array}$ & $\begin{array}{c}\text { Oceanic } \\
\text { Mean } \pm \text { SD }\end{array}$ & $\mathrm{R}^{2}$ \\
\hline Salinity & $31.4 \pm 1.59$ & $36.3 \pm 0.51$ & $0.68^{* * *}$ \\
\hline \multicolumn{4}{|c|}{ Accessory pigments (\% chl a) } \\
\hline Chlorophyll c1c2 & $29.6 \pm 6.3$ & $20.6 \pm 5.5$ & 0.24 \\
\hline Fucoxanthin & $15.5 \pm 4.8$ & $6.2 \pm 2.3$ & $0.47^{*}$ \\
\hline Diadinoxanthin & $8.2 \pm 4.6$ & $3.2 \pm 1.8$ & $0.38^{*}$ \\
\hline Zeaxanthin & $9.6 \pm 3.8$ & $28.4 \pm 8.6$ & $0.75^{* * *}$ \\
\hline \multicolumn{4}{|l|}{ Nutrients $\left(\mu \mathrm{mol} \mathrm{l}^{-1}\right)$} \\
\hline $\mathrm{NO}_{3}^{-}$ & $0.07 \pm 0.06$ & $0.08 \pm 0.06$ & $0.05^{\mathrm{a}}$ \\
\hline $\mathrm{HPO}_{4}^{+}$ & $0.16 \pm 0.10$ & $0.15 \pm 0.08$ & 0.13 \\
\hline $\mathrm{SiO}_{2}$ & $0.32 \pm 0.22$ & $0.87 \pm 0.30$ & $0.49^{*}$ \\
\hline $\mathrm{NH}_{4}^{+}$ & $0.94 \pm 0.69$ & $1.55 \pm 1.55$ & 0.19 \\
\hline $\mathrm{NO}_{2}^{-}$ & $0.12 \pm 0.07$ & $0.07 \pm 0.08$ & 0.22 \\
\hline Urea & $0.33 \pm 0.10$ & $0.32 \pm 0.26$ & 0.11 \\
\hline DIN:P & $9.0 \pm 6.0$ & $11.9 \pm 8.1$ & $0.48^{*}$ \\
\hline Molar C:N & $7.9 \pm 2.1$ & $5.8 \pm 0.6$ & 0.22 \\
\hline
\end{tabular}




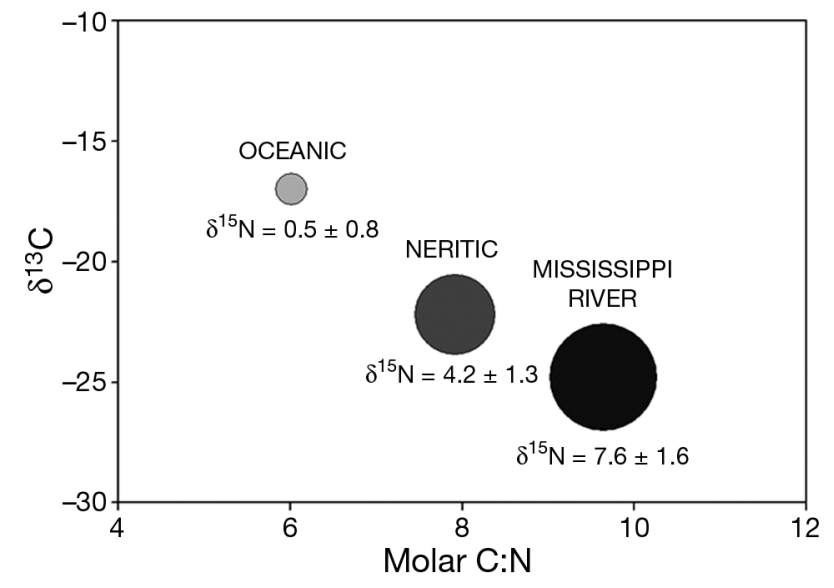

Fig. 4. Bubble cross-plot of $\delta^{13} \mathrm{C}$ and molar C:N values of POM. Neritic and oceanic POM station averages are compared to average POM values from the Mississippi River (Wissel \& Fry $2005 \mathrm{~b}$ ), and symbol size indicates relative $\delta^{15} \mathrm{~N}$ values

DIN concentrations were at the lower end of the typical range of values measured in the GOM at the neritic and oceanic stations (Lambert et al. 1999, Quigg et al. 2011). Furthermore, $\mathrm{NO}_{3}{ }^{-}$concentrations were below the limit of detection in all samples, and DIN:P ratios indicated that both environments were $\mathrm{N}$ limited. $\mathrm{HPO}_{4}{ }^{-}$concentrations were similar in both environments. $\mathrm{SiO}_{2}$ was the only nutrient to correlate with the NMDS solution (Table 3), and values at neritic stations were decreased relative to those at oceanic stations (Fig. 3). This suggests that there was a greater utilization of $\mathrm{SiO}_{2}$ by the phytoplankton community at neritic stations. This finding is consistent with pigment data, which showed an increase in the abundance of diatoms (as fucoxanthin and diadinoxanthin) at neritic stations relative to oceanic stations (Table 3, Fig. 3). DIN:P values in both the neritic and oceanic water masses indicate overall $\mathrm{N}$ limitation, but the slight increase in DIN:P at oceanic stations suggests that $\mathrm{N}$ limitation was more widespread at neritic stations. The products of diazotrophy include $\mathrm{NH}_{4}{ }^{+}$and dissolved organic $\mathrm{N}$ compounds, and our results show elevated $\mathrm{NH}_{4}{ }^{+}$concentrations at oceanic stations. DIN:P ratios and $\mathrm{NH}_{4}{ }^{+}$concentrations measured from oceanic stations may signify that $\mathrm{N}_{2}$ fixation slightly alleviates $\mathrm{N}$ limitation in areas where there is an increase in cyanobacteria.

Molar C:N has been used in conjunction with $\delta^{13} \mathrm{C}$ and $\delta^{15} \mathrm{~N}$ values to evaluate the sources of POM in the Mississippi River (Wissel \& Fry 2005b, Wissel et al. 2005). We compare POM C:N values measured at our stations to those from the Mississippi River to further elucidate trends in our data (Fig. 4). POM $\mathrm{C}: \mathrm{N}$ values at oceanic stations were characteristic of phytoplankton and bacteria (Wissel \& Fry 2005b) and were lower $(5.8 \pm 0.5)$ relative to neritic stations $(8.1 \pm$ 2.4). POM C:N ratios measured from the Mississippi River are higher $(9.6 \pm 1.0)$ (Wissel \& Fry 2005b), and our POM C:N ratios from neritic stations approached these values. Furthermore, the increase in POM molar C:N between oceanic and neritic environments is also accompanied by an increase in $\delta^{15} \mathrm{~N}$ values (Fig. 4), suggesting that POM measured at neritic stations was influenced by DIN originating from and transported by the Mississippi and Atchafalaya rivers.

\section{DISCUSSION}

The loop-hole theory by Bakun \& Broad (2003) suggests that large pelagic fishes use nutrient-depleted environments to spawn because for their larvae the benefits from decreased predation offset the costs of minimal resources. This concept has also been used to describe the success of pelagic fish larvae in the Straits of Florida, but questions remain regarding the mechanisms by which prey items are supported in this open ocean environment as these regions are characterized by decreased primary production (Llopiz \& Cowen 2008). The role of diazotrophy in supporting higher trophic levels in these areas has not been widely investigated, and we present data that suggest $\mathrm{N}_{2}$ fixation is important for sustaining ecologically and economically important pelagic fish species (e.g. billfishes and dolphinfishes) in the GOM. This may help to explain previous research which shows tropical and sub-tropical low latitude pelagic environments as important spawning, nursery, and foraging habitat for pelagic fishes despite their oligotrophic nature (Block et al. 2005, Llopiz \& Cowen 2008, Rooker et al. 2008, Simms et al. 2009, Teo \& Block 2010, Kraus et al. 2011).

Depleted $\delta^{15} \mathrm{~N}$ values of producers and consumers have been used to describe the relative importance of diazotrophy for marine food webs and explain differences in $\mathrm{N}$ cycling between basins (Montoya et al. 2002, Capone et al. 2005, Pajuelo et al. 2010). Here, we apply these concepts to explain differences in our stable isotope data and compare a collection of published data from the GOM to assess basin scale differences in consumer groups. Our results indicate that $\mathrm{N}$ derived from diazotrophy is used by consumers in offshore environments; this supports previous research which speculates that $\mathrm{N}_{2}$ fixation (primarily by Trichodesmium) is important in the GOM (Mulholland et al. 2006, Holl et al. 2007). We also found the inputs from diazotrophy were tempered by 
freshwater, and terrestrial N sources support production in entrainments of neritic waters. Trophic models using stable isotopes as dietary markers should take into account the use of combined $\mathrm{N}$ from diazotrophy and freshwater inputs, which we show are significant sources of $\mathrm{N}$ in surface waters of the GOM.

\section{Neritic and oceanic differences}

Our analyses proved useful in showing that inputs from the Mississippi River system and $\mathrm{N}_{2}$ fixation influence pelagic food webs in the GOM. $\delta^{13} \mathrm{C}$ and $\delta^{15} \mathrm{~N}$ values of POM and zooplankton from neritic water masses (salinity < 32) were significantly different from those collected in oceanic water masses (salinity $\geq 32$ ). POM $\delta^{13} \mathrm{C}$ values were enriched and $\delta^{15} \mathrm{~N}$ values were depleted in the oceanic water masses relative to published values, which have been shown to range from -18 to $-25 \%$ for $\delta^{13} \mathrm{C}$ and -2 to $8 \%$ for $\delta^{15} \mathrm{~N}$ in the GOM (Table 1) (Thayer et al. 1983). We attribute the differences between the present findings and those previously published to the presence of Trichodesmium colonies in the concentrated POM samples collected herein. This is consistent with published literature that indicates this diazotroph is unique in having the most enriched $\delta^{13} \mathrm{C}$ and depleted $\delta^{15} \mathrm{~N}$ values compared to any other marine phytoplankton (Carpenter et al. 1997, Tchernov \& Lipschultz 2008). Data from a 2 yr study described the POM from the Mississippi River as having an average $\delta^{15} \mathrm{~N}$ value of $\sim 7 \%$ (Wissel \& Fry $2005 \mathrm{~b})$, which is enriched compared to that of POM from oceanic origins. Our $\delta^{15} \mathrm{~N}$ values measured from POM in neritic water masses approached this value $(4.2 \pm 1.3)$, suggesting the use of a mixture of $\mathrm{N}$ sources by the phytoplankton community in these environments. The difference can be explained by the use of DIN derived from the terrestrial environment in the neritic environment relative to an isotopically depleted source in the oceanic one. The pool of DIN in the Mississippi River is likely enriched because of the fractionation associated with the denitrification of $\mathrm{NO}_{3}{ }^{-}$or the nitrification and volatilization of $\mathrm{NH}_{4}{ }^{+}$originating from terrestrial runoff, sewage, and groundwater (Montoya 2008).

In the oceanic regions, depleted POM $\delta^{15} \mathrm{~N}$ values may have resulted from the presence of Trichodesmium in samples. However, results from isolated zooplankton mirror shifts in the POM, where $\delta^{15} \mathrm{~N}$ values were on average $3 \%$ o depleted in oceanic compared to neritic water masses. Similarity in zooplankton $\delta^{13} \mathrm{C}$ values between oceanic and neritic samples points to the use of a similar carbon source. This indicates that shifts in $\delta^{15} \mathrm{~N}$ are not driven by differences in the type of food being assimilated but rather that $\mathrm{N}$ derived from diazotrophy is incorporated into the tissues of higher trophic levels in marine water masses. This finding is consistent with previous work that reports depleted $\delta^{15} \mathrm{~N}$ values in consumers where diazotrophy contributed significant inputs of new nitrogen (Montoya et al. 2002, Capone et al. 2005, Holl et al. 2007). Furthermore, enriched zooplankton $\delta^{15} \mathrm{~N}$ values collected from surface water with decreased salinity further support the use of differential nitrogen sources in the GOM. Zooplankton from neritic water masses are likely supported by phytoplankton using $\mathrm{N}$ originating from the terrestrial environment. The results of our analyses show that different $\mathrm{N}$ sources have the potential to confound isotope-based estimates of trophic position and hence the interpretation of food web models that use stable isotopes as dietary markers. Documenting these consumer differences is significant because the distribution and abundance of Trichodesmium in the GOM have not been sufficiently studied, and this genus has been overlooked as a significant source of N supporting primary production.

Trends in our stable isotope data are consistent with SSH and SSC maps that depict a freshwater plume being entrained into oceanic surface waters in July, despite the study area being $\sim 100$ to $350 \mathrm{~km}$ from the mouth of the Mississippi River (see Fig. S1 in the supplement). Depleted $\delta^{15} \mathrm{~N}$ values were more widespread in June, when neritic water masses were not encountered, indicating that the role of Trichodesmium in supporting production within our sampling corridor was highly dependent on the magnitude of freshwater received from the neritic environment. This is supported by the observation that Trichodesmium colonies were visible at all stations in June but were only present at stations that exhibited higher salinity in July. The lack of Trichodesmium in lower salinity water masses reflects its documented preference for the tropical oceanic environment (La Roche \& Breitbarth 2005, Breitbarth et al. 2007).

Furthermore, our findings that the relative abundance of cyanobacteria was significantly increased in marine stations is in agreement with previous studies that describe the phytoplankton community of LC surface waters being dominated by small-sized phytoplankton and cyanobacteria, such as Trichodesmium (Biggs \& Ressler 2001). In addition, depthintegrated Trichodesmium abundance in the western GOM was measured by Holl et al. (2007) to be $4.1 \times$ 
$10^{8} \pm 3 \times 10^{8}$ trichomes $\mathrm{m}^{-2}$, but when only considering oligotrophic stations farthest offshore (between 26 to $27^{\circ} \mathrm{N}$ and 94 to $96^{\circ} \mathrm{W}$ ), values increased to $7.3 \times$ $10^{8} \pm 5.4 \times 10^{8}$ trichomes $\mathrm{m}^{-2}$. In contrast, the contribution of chlorophyll $c 1 c 2$, fucoxanthin, and diadinoxanthin was increased in the neritic stations, which reflects an increase in the relative abundance of diatoms, dinoflagellates, and other eukaryotic phytoplankton. This also agrees with previous studies in the GOM which showed an increase in diatom abundance inshore (Lambert et al. 1999). Molar C:N and $\delta^{15} \mathrm{~N}$ values measured in neritic water masses were similar to those measured from POM collected from the Mississippi River, suggesting that the presence of freshwater fueled the production of eukaryotic phytoplankton. This is consistent with data collected by Qian et al. (2003), who found that the spatial distribution of chlorophyll $a$ and the phytoplankton community composition were controlled by riverine inputs of nutrient enriched freshwater.

\section{Isotope baseline shift}

POM and Sargassum have been shown to contribute organic matter to food webs in regions of the northern GOM that serve as spawning habitat for important pelagic fishes (Wells \& Rooker 2009). The stable isotope data from Wells \& Rooker (2009) suggest that $\mathrm{N}_{2}$ fixation by Trichodesmium may be important in supporting these populations. Previous literature has shown that Trichodesmium indirectly supports production by releasing $\mathrm{NH}_{4}{ }^{+}$and dissolved organic $\mathrm{N}$ compounds, such as amino acids, into its immediate environment during $\mathrm{N}_{2}$ fixation (Mulholland \& Capone 2000, Mulholland et al. 2006). These products have been documented to be used by other components of the food web, such as phytoplankton (Mulholland et al. 2006) and heterotrophic bacteria (Biddanda \& Benner 1997), which are then available for consumption by higher trophic levels (Landry et al. 2001, Montoya et al. 2002, Holl et al. 2007). N* models suggest $\mathrm{N}_{2}$ fixation may contribute excess $\mathrm{N}$ to the northwest Atlantic Ocean and other subtropical regions, such as the GOM, which supports the indirect use of $\mathrm{N}$ derived from Trichodesmium (Gruber \& Sarmiento 1997, Capone et al. 2005). Furthermore, depleted $\delta^{15} \mathrm{~N}$ values of deep-water (200 to $600 \mathrm{~m}$ ) DIN pools measured in the western GOM suggest that widespread $\mathrm{N}_{2}$ fixation by Trichodesmium occurs in this region (Holl et al. 2007). Presumably, if the phytoplankton community is utilizing this DIN, there would be a trophic transfer of this nitrogen pool up the food web, and consumer $\delta^{15} \mathrm{~N}$ values would become depleted relative to consumers from areas where DIN inputs from $\mathrm{N}_{2}$ fixation is ancillary (Montoya et al. 2002). The results of the present study support this concept, as zooplankton isotope values from oceanic areas where Trichodesmium was abundant were significantly depleted when compared to zooplankton collected from neritic water masses.

Pajuelo et al. (2010) measured the isotope signatures of juvenile loggerhead sea turtles Caretta caretta encountered in the northeast Atlantic and the southeast Pacific Ocean to decribe basin-scale differences in $\mathrm{N}$ cycling. Depletion in the $\delta^{15} \mathrm{~N}$ values of the consumers collected from the Atlantic was attributed to increased $\mathrm{N}^{2}$ fixation in that region when compared to Pacific consumers whose nitrogen isotope values suggest denitrified sources are more important (Pajuelo et al. 2010). The present study postulated that the depletion in $\delta^{15} \mathrm{~N}$ values measured in this consumer was due to increased $\mathrm{N}_{2}$ fixation in the Atlantic compared to the Pacific, where denitrified sources were more important. A comparison of stable isotope data of producers and consumers from the GOM to consumer data from Pajuelo et al. (2010) shows an isotopic baseline shift between neritic and oceanic environments in the GOM similar to that reported to occur between the Atlantic and Pacific Oceans (Fig. 5). This evidence suggests that there are differences in $\mathrm{N}$ cycling between neritic and oceanic water masses in the GOM that are driven by diazotrophy and freshwater inputs. Results of this comparison study parallel our data in that $\delta^{13} \mathrm{C}$ values of producers and consumers are relatively stable, while $\delta^{15} \mathrm{~N}$ values are enriched in neritic relative to oceanic data. This suggests that similar functional groups in the 2 environments use different nitrogen sources.

Sargassum $\delta^{15} \mathrm{~N}$ values were depleted $\sim 2 \%$ at oceanic stations compared to neritic stations, and a shift in isotope values suggests that this producer uses different $\mathrm{N}$ sources when available. Previous literature reports enhanced production of Sargassum when inorganic N was added to incubations (LaPointe 1995). In addition, Sargassum has been shown to use both inorganic and organic forms of $\mathrm{N}\left(\mathrm{NH}_{4}{ }^{+}, \mathrm{NO}_{3}{ }^{-}\right.$, urea, and amino acids) (Vonk et al. 2008) and is able to exploit nutrients from POM remineralized by associated microbes that reside on its thallus (Schaffelke 1999). Uptake of $\mathrm{N}$ from diazotrophic epiflora has been shown to support Sargassum in the Sargasso Sea and Gulf Stream (Hanson 1977), and it is therefore reasonable to suspect that $\mathrm{N}$ compounds released by Trichodesmium are incorporated into populations of Sargassum in the GOM. This macroalgae has been 


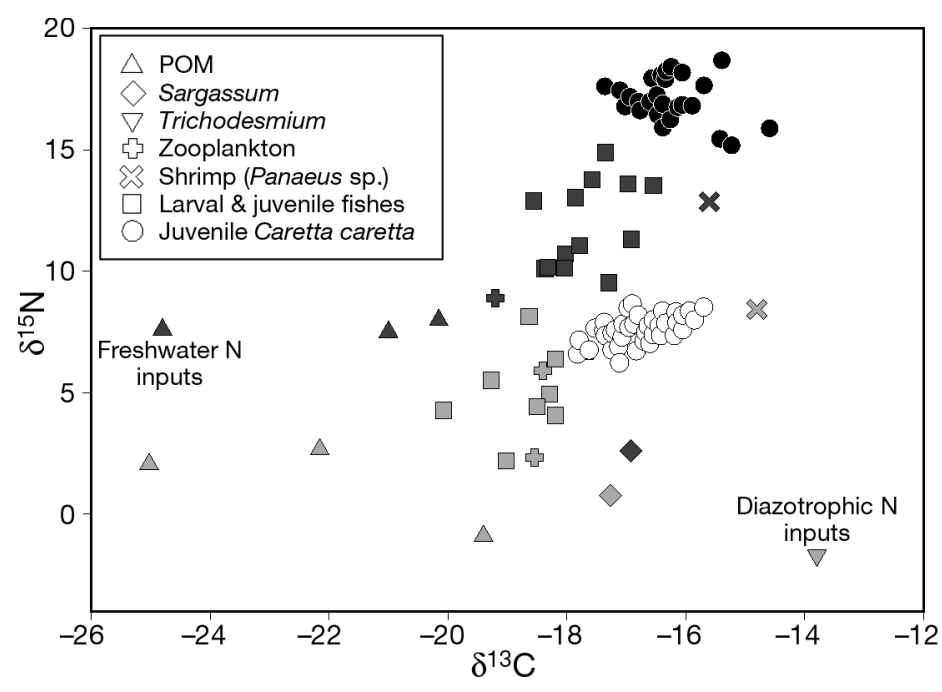

Fig. 5. Producer and consumer stable isotope $\left(\delta^{13} \mathrm{C}\right.$ and $\left.\delta^{15} \mathrm{~N}\right)$ values from neritic (dark grey) and oceanic (light grey) food webs of the Gulf of Mexico (Table 2) compared to isotope values of juvenile loggerhead sea turtles Caretta caretta taken from the Pacific (•) and Atlantic (O) oceans. Sources of nitrogen for surface communities in the Gulf of Mexico include freshwater (Mississippi and Atchafalaya rivers) and diazotrophy (Trichodesmium)

classified as essential fish habitat (SAFMC 2002), but its importance as a direct food source has been shown to be eclipsed by its value as a physical habitat and substrate for epibionts (Rooker et al. 2006). The uptake of fixed $\mathrm{N}$ originating from Trichodesmium may therefore play an additional indirect role in supporting fish production by contributing to the success of Sargassum populations in the GOM.

Consumer $\delta^{13} \mathrm{C}$ values fall within the -20 to $-14 \%$ range and POM is likely the major contributor of organic matter to higher trophic levels. This has been documented in the GOM (Rooker et al. 2006, Wells \& Rooker 2009), and consumer $\delta^{13} \mathrm{C}$ values that are not centered around $-14 \%$ suggest Trichodesmium is not directly grazed upon. Instead, we postulate that $\mathrm{N}$ compounds released from Trichodesmium are directly used or transformed into isotopically light $\mathrm{NO}_{3}{ }^{-}$before being incorporated into the food web. The collection of data from the GOM supports this theory, as $\delta^{15} \mathrm{~N}$ values of zooplankton, shrimp (Panaeus sp.), and fish assemblages were depleted in the oceanic food webs compared to the neritic ones. The magnitudes of change differ among consumer groups, likely resulting from variation in the species composition of the assemblages, differences in prey preference among those species, and inconsistency in diet among similar species, such as the advancement to piscivory in larval fish (Wells \& Rooker 2009).

Nevertheless, consumer data are consistent with data from Pajuelo et al. (2010), who show that the $\delta^{15} \mathrm{~N}$ values of juvenile Caretta caretta are depleted in environments where $\mathrm{N}_{2}$ fixation impacts the isotopic baseline of organisms in the northeast Atlantic Ocean. Data not included in our analysis also support the varying use of $\mathrm{N}$ within regions of the GOM. Brown shrimp Farfantepenaeus aztecus collected from inshore and offshore environments off the coast of Louisiana exhibited distinct $\delta^{15} \mathrm{~N}$ values resulting from riverine inputs (Fry 2011). Furthermore, Senn et al. (2010) found $\delta^{15} \mathrm{~N}$ values from adult fishes collected from coastal regions in the GOM were generally enriched $(10.8 \pm 0.8 \mathrm{SD}$ to $15.6 \pm 0.2)$ compared to those collected from oceanic environments $(9.7 \pm 1.4$ to $12.4 \pm 1.0)$. Another example of disparate consumer $\delta^{15} \mathrm{~N}$ values is that of adult blue marlin, which averaged $\sim 10 \%$ o (Cai et al. 2007), i.e. less than the $\delta^{15} \mathrm{~N}$ values measured from juvenile fish by Rooker et al. (2006). This example was not included in Fig. 5 to avoid excessive overlap, but blue marlin are described as oceanic apex predators that feed at the top of pelagic food webs. The discrepancy in isotope values can only be explained by an isotopic baseline shift resulting from consuming prey supported by isotopically depleted $\mathrm{N}$.

This collection of data indicates that products of diazotrophy from Trichodesmium are not only utilized by phytoplankton, bacteria, and zooplankton but are also incorporated into Sargassum communities and fish tissues, providing a mechanism for the success of higher trophic levels in oligotrophic environments. Our results demonstrate that diazotrophy is important in the GOM and that the prevalence of Trichodesmium will alter stable isotopic baselines. Our findings support the new paradigm that diazotrophy is prominent in the open ocean, and Trichodesmium should be considered an important producer in areas where it is abundant. Validating the influence of diazotrophs in the GOM will help to explain production in areas where traditional $\mathrm{N}$ inputs, such as the upwelling of $\mathrm{NO}_{3}{ }^{-}$, have been shown to be minimal. Alternatively, differences in the composition of POM and variation in the fractionation of $\mathrm{N}$ between the neritic and oceanic environments may explain disparate isotope values. In addition, the role of atmospheric deposition of inorganic $\mathrm{N}$ in supporting phytoplankton growth (Prospero et al. 1996) and the preferential export of ${ }^{15} \mathrm{~N}$ from the euphotic zone (Altabet 1988) should be investigated in the GOM as these mechanisms may also lead to depleted $\delta^{15} \mathrm{~N}$ values of particulates. 


\section{Conclusion}

We used the natural abundance of stable isotopes to show that shifts in isotopic baselines of food webs in the GOM could be attributed to differences in $\mathrm{N}$ sources between neritic and oceanic water masses. Enriched $\delta^{15} \mathrm{~N}$ values of POM and zooplankton collected from neritic stations reflected the use of $\mathrm{N}$ sources originating from the terrestrial environment. In contrast, depleted $\delta^{15} \mathrm{~N}$ values of the POM and zooplankton at oceanic stations highlighted the importance of Trichodesmium in these environments, where $\mathrm{N}$ from diazotrophy supports secondary production. Salinity, silicate concentrations, DIN:P ratios, phytoplankton community composition, and molar C:N ratios were significantly different between neritic and oceanic water masses, allowing us to attribute variation in isotope signatures to freshwater inputs. When data are compared to shifts in isotope values resulting from differences in basin scale $\mathrm{N}$ cycling, it becomes apparent that food webs in the GOM use different sources of $\mathrm{N}$. The isotopes of producers and consumers measured at oceanic stations in the GOM were useful in identifying diazotrophy by Trichodesmium as an important process that contributes to the production of higher order consumers, such as larval and juvenile fishes. Diazotrophy and freshwater inputs should be considered in future efforts that describe pelagic food webs in other regions. Compound specific research focused on pathways by which $\mathrm{N}$ and $\mathrm{C}$ originating from Trichodesmium are incorporated into higher trophic levels will further validate the role of diazotrophy in sustaining oligotrophic food webs.

Acknowledgements. We thank A. McInnes, J. Steichen, and other members of the Phytoplankton Dynamics Laboratory for invaluable participation in fieldwork and sample processing. In addition, we thank the captain and crew of the RV 'Ladybride' for their support at sea. Funding for this project was provided by the McDaniel Charitable Foundation; support for S.D. was provided by the Texas Institute of Oceanography and grants from NOAA. We thank the 3 anonymous reviewers for helpful comments which improved the manuscript.

\section{LITERATURE CITED}

Altabet MA (1988) Variations in nitrogen isotopic composition between sinking and suspended particles: implications for nitrogen cycling and particle transformation in the open-ocean. Deep-Sea Res Part A 35:535-554

$>$ Altabet MA, Robinson AR, Walstad LJ (1986) A model for the vertical flux of nitrogen in the upper ocean: simulating the alteration of isotopic ratios. J Mar Res 44:203-225

Bakun A, Broad K (2003) Environmental 'loopholes' and fish population dynamics: comparative pattern recognition with focus on El Niño effects in the Pacific. Fish Oceanogr 12:458-473
Biddanda B, Benner R (1997) Major contribution from mesopelagic plankton to heterotrophic metabolism in the upper ocean. Deep-Sea Res I 44:2069-2085

Biggs DC, Ressler PH (2001) Distribution and abundance of phytoplankton, zooplankton, ichthyoplankton, and micronekton in the deepwater Gulf of Mexico. Gulf Mex Sci 19:7-29

> Biggs DC, Hu C, Müller-Karger FE (2008) Remotely sensed sea-surface chlorophyll and POC flux at Deep Gulf of Mexico Benthos sampling stations. Deep-Sea Res II 55: 2555-2562

Block BA, Teo SLH, Walli A, Boustany A and others (2005) Electronic tagging and population structure of Atlantic bluefin tuna. Nature 434:1121-1127

Breitbarth E, Oschlies A, Laroche J (2007) Physiological constraints on the global distribution of Trichodesmiumeffect of temperature on diazotrophy. Biogeosciences 4: 53-61

Cai Y, Rooker JR, Gill GA, Turner JP (2007) Bioaccumulation of mercury in pelagic fishes from the northern Gulf of Mexico. Can J Fish Aquat Sci 64:458-469

> Capone DG, Burns JA, Montoya JP, Subramaniam A and others (2005) Nitrogen fixation by Trichodesmium spp.: an important source of new nitrogen to the tropical and subtropical North Atlantic Ocean. Global Biogeochem Cycles 19:1-17

Carpenter EJ, Harvey HR, Fry B, Capone DG (1997) Biogeochemical tracers of the marine cyanobacterium Trichodesmium. Deep-Sea Res I 44:27-38

Dagg MJ, Breed GA (2003) Biological effects of Mississippi River nitrogen on the northern Gulf of Mexico-a review and synthesis. J Mar Syst 43:133-152

> Dugdale RC, Goering JJ (1967) Uptake of new and regenerated forms of nitrogen in primary productivity. Limnol Oceanogr 12:196-206

> Eppley RW, Peterson BJ (1979) Particulate organic matter flux and planktonic new production in the deep ocean. Nature 282:677-680

Fry B (1983) Fish and shrimp migrations in the northern Gulf of Mexico analyzed using stable $\mathrm{C}, \mathrm{N}$, and $\mathrm{S}$ isotope ratios. Fish Bull 81:789-801

Fry B (2008) Stable isotope ecology. Springer Science, New York, NY

Fry B (2011) Mississippi River sustenance of brown shrimp (Farfantepenaeus aztecus) in Louisiana coastal waters. Fish Bull 109:147-161

> Gruber N, Sarmiento JL (1997) Global patterns of marine nitrogen fixation and denitrification. Global Biogeochem Cycles 11:235-266

> Hanson RB (1977) Pelagic Sargassum community metabolism: carbon and nitrogen. J Exp Mar Biol Ecol 29:107-118

> Holl CM, Villareal TA, Payne CD, Clayton TD, Hart CM, Montoya JP (2007) Trichodesmium in the western Gulf of Mexico: ${ }^{15} \mathrm{~N}_{2}$-fixation and natural abundance stable isotopic evidence. Limnol Oceanogr 52:2249-2259

> Howarth RW, Marino R (2006) Nitrogen as the limiting nutrient for eutrophication in coastal marine ecosystems: evolving views over 3 decades. Limnol Oceanogr 51: 364-376

> Kraus RT, Wells RJD, Rooker JR (2011) Horizontal movement of Atlantic blue marlin (Makaira nigricans) in the Gulf of Mexico. Mar Biol 158:699-713

$>$ La Roche J, Breitbarth E (2005) Importance of the diazotrophs as a source of new nitrogen in the ocean. J Sea Res 53:67-91

$>$ Lambert CD, Bianchia TS, Santschi PH (1999) Cross-shelf changes in phytoplankton community composition in the 
Gulf of Mexico (Texas shelf/slope): the use of plant pigments as biomarkers. Cont Shelf Res 19:1-21

Landry MR, Al-Mutairi H, Selph KE, Chistensen S, Nunnery S (2001) Seasonal patterns of mesozooplankton abundance and biomass at Station ALOHA. Deep-Sea Res I 48:2037-2061

LaPointe BE (1995) A comparison of nutrient-limited productivity in Sargassum natans from neritic vs. oceanic waters of the western North Atlantic Ocean. Limnol Oceanogr 40:625-633

Llopiz JK, Cowen RK (2008) Precocious, selective and successful feeding of larval billfishes in the oceanic Straits of Florida. Mar Ecol Prog Ser 358:231-244

> Macko S, Entzeroth L, Parker P (1984) Regional differences in nitrogen and carbon isotopes on the continental shelf of the Gulf of Mexico. Naturwissenschaften 71:374-375

Minagawa W, Wada E (1986) Nitrogen isotopes of red tide organisms in the East China Sea: a characterization of biological nitrogen fixation. Mar Chem 19:245-259

Montoya JP (2008) Nitrogen stable isotopes in marine environments. In: Capone DG, Bronk DA, R. MM, Carpenter EJ (eds) Nitrogen in the marine environment. Elsevier, San Diego, CA

Montoya JP, Carpenter EJ, Capone DG (2002) Nitrogen fixation and nitrogen isotope abundances in zooplankton of the oligotrophic north Atlantic. Limnol Oceanogr 47: 1617-1628

Mulholland MR, Capone DG (2000) The nitrogen physiology of the marine $\mathrm{N}_{2}$-fixing cyanobacteria Trichodesmium spp. Trends Plant Sci 5:148-153

Mulholland MR, Bernhardt PW, Heil CA, Bronk DA, O'Neil JM (2006) Nitrogen fixation and release of fixed nitrogen by Trichodesmium spp. in the Gulf of Mexico. Limnol Oceanogr 51:1762-1776

Oksanen JF, Kindt R, Legendre L, O'Hara B and others (2009) Vegan: community ecology package. R package version 1.15-2. R Foundation for Statistical Computing, Vienna. http://CRAN.R-project.org/package=vegan

Olli K, Klais R, Tamminen T, Ptacnik R, Anderson T (2011) Long term changes in the Baltic Sea phytoplankton community. Boreal Environ Res 16:3-14

Pajuelo M, Bjorndal KA, Alfaro-Shigueto J, Seminoff JA, Mangel JC, Bolten AB (2010) Stable isotope variation in loggerhead turtles reveals Pacific-Atlantic oceanographic differences. Mar Ecol Prog Ser 417:277-285

Pallant J (2010) SPSS survival manual. Open University Press, New York, NY

> Peterson BJ, Fry B (1987) Stable isotopes in ecosystem studies. Annu Rev Ecol Syst 18:293-320

> Post DM (2002) Using stable isotopes to estimate trophic position: models, methods, and assumptions. Ecology 83: 703-718

Prospero JM, Barrett K, Church T, Dentener F and others (1996) Atmospheric deposition of nutrients to the North Atlantic Basin. Biogeochemistry 35:27-73

Qian Y, Jochens AE, Kennicutt MC, Biggs DC (2003) Spatial and temporal variability of phytoplankton biomass and community structure over the continental margin of the northeast Gulf of Mexico based on pigment analysis. Cont Shelf Res 23:1-17

> Quigg A, Sylvan JB, Gustafson AB, Fisher TR, Tozzi S, Ammerman JW (2011) Going west: nutrient limitation of primary production in the northern Gulf of Mexico and the importance of the Atchafalaya River. Aquat Geochem 17:519-544

Rooker JR, Turner JP, Holt SA (2006) Trophic ecology of Sar-

Editorial responsibility: Antonio Bode,

A Coruña, Spain gassum-associated fishes in the Gulf of Mexico determined from stable isotopes and fatty acids. Mar Ecol Prog Ser 313:249-259

> Rooker JR, Secor DH, De Metrio G, Schloesser R, Block BA, Neilson JD (2008) Natal homing and connectivity in Atlantic bluefin tuna populations. Science 322:742-744

SAFMC (South Atlantic Fishery Management Council) (2002) Fishery management plan for Sargassum habitat of the South Atlantic region. South Atlantic Fishery Management Council, Charleston, SC

Schaffelke B (1999) Particulate organic matter as an alternative nutrient source for tropical Sargassum species (Fucales, Phaeophyceae). J Phycol 35:1150-1157

Senn DB, Chesney EJ, Blum JD, Bank MS, Maage A, Shine JP (2010) Stable isotope (N, C, Hg) study of methylmercury sources and trophic transfer in the northern Gulf of Mexico. Environ Sci Technol 44:1630-1637

Sieburth JM, Smetacek V, Lenz J (1978) Pelagic ecosystem structure: heterotrophic compartments of the plankton and their relationship to plankton size fractions. Limnol Oceanogr 23:1256-1263

Simms JR, Holt S, Holt JG, Bangma J, Rooker JR (2009) Age and growth of larval sailfish, Istiophorus platypterus, in the northern Gulf of Mexico. Proc Gulf Caribb Fish Inst 61:17-21

Tchernov D, Lipschultz F (2008) Carbon isotopic composition of Trichodesmium spp. colonies off Bermuda: effects of colony mass and season. J Plankton Res 30:21-31

Teo SLH, Block BA (2010) Comparative influence of ocean conditions on yellowfin and Atlantic bluefin tuna catch from longlines in the Gulf of Mexico. PLoS ONE 5:e10756

Thayer GW, Govoni JJ, Connally DW (1983) Stable carbon isotope ratios of the planktonic food web in the northern Gulf of Mexico. Bull Mar Sci 33:247-256

> Vonk JA, Middelburg JJ, Stapel J, Bouma TJ (2008) Dissolved organic nitrogen uptake by seagrasses. Limnol Oceanogr 53:542-548

Walker ND, Wiseman WJ, Rouse LJ, Babin A (2005) Effects of river discharge, wind stress, and slope eddies on circulation and the satellite-observed structure of the Mississippi River plume. J Coast Res 21:1228-1244

- Walsh JJ, Dieterle AD, Meyers MB, Müller-Karger FE (1989) Nitrogen exchange at the continental margin: a numerical study of the Gulf of Mexico. Prog Oceanogr 23: 245-301

> Wells RJD, Rooker JR (2009) Feeding ecology of pelagic fish larvae and juveniles in slope waters of the Gulf of Mexico. J Fish Biol 75:1719-1732

Wissel B, Fry B (2005a) Tracing Mississippi River influences in estuarine food webs of coastal Louisiana. Oecologia 144:659-672

Wissel B, Fry B (2005b) Sources of particulate organic matter in the Mississippi River, USA. Arch Hydrobiol 155: 105-118

Wissel B, Gace A, Fry B (2005) Tracing river influences on phytoplankton dynamics in two Louisiana estuaries. Ecology 86:2751-2762

> York JK, Tomasky G, Valiela I, Repeta DJ (2007) Stable isotopic detection of ammonium and nitrate assimilation by phytoplankton in the Waquoit Bay estuary system. Limnol Oceanogr 52:144-155

Zehr JP, Mellon MT, Zani S (1998) New nitrogen-fixing microorganisms detected in oligotrophic oceans by amplification of nitrogenase (nifH) genes. Appl Environ Microbiol 64:3444-3450

Submitted: December 14, 2011; Accepted: May 29, 2012

Proofs received from author(s): September 14, 2012 